American Journal of Applied Sciences 5 (12): 1650-1661, 2008

ISSN 1546-9239

(C) 2008 Science Publications

\title{
Characterization and Wash Performance Analysis of Microbial Extracellular Enzymes from East Calcutta Wetland in India
}

\author{
${ }^{1}$ Ramesh Malathu, ${ }^{1}$ Sanhita Chowdhury, ${ }^{1}$ Madhusmita Mishra, ${ }^{1}$ Sumana Das, ${ }^{1}$ Prabhat Moharana, \\ ${ }^{1}$ Joydeep Mitra, ${ }^{2}$ Ujjal K. Mukhopadhyay, ${ }^{1}$ Ashoke Ranjan Thakur and ${ }^{1}$ Shaon Ray Chaudhuri \\ ${ }^{1}$ Department of Biotechnology, West Bengal \\ University of Technology, BF-142, Sector 1, Salt Lake, Calcutta-700064, India \\ ${ }^{2}$ West Bengal Pollution Control Board, Paribesh Bhawan, 10A, Block-LA \\ Sector III, Salt Lake, Calcutta-700098, India
}

\begin{abstract}
Extracellular protease from a novel bacterial isolate showing maximum similarity of 98.22\% with Microbacterium luteolum was obtained from East Calcutta Wetland, India. It showed compatibility with commercial detergents. The enzyme retains more than $60 \%$ of its activity between 6.0 to $10.5 \mathrm{pH}$. The maximum activity is at $\mathrm{pH} 7.5$ with $71 \%$ activity at $\mathrm{pH} 10.0$ and 10.5 . The protease retained its activity between 4 to $60^{\circ} \mathrm{C}$ with maximum activity at $30^{\circ} \mathrm{C}$ and a residual activity of $74.4 \%$ at $60^{\circ} \mathrm{C}$ after overnight incubation. It was completely inhibited by $5 \mathrm{mM}$ PMSF pointing towards the presence of serine group of protease. Its inhibition by EDTA indicates the involvement of metal cations in its catalytic activity. It is not effected by $\mathrm{Cu}^{+2}$, partially inhibited by $\mathrm{Pb}^{+2}$ and $\mathrm{Ni}^{+2}$, while completely inhibited by $\mathrm{Co}^{+1}, \mathrm{Cr}^{+6}, \mathrm{Zn}^{+1}, \mathrm{Al}^{+3}, \mathrm{Ag}^{+3}$ and $\mathrm{Hg}^{+2}$. Strong reducing agents like $\beta$ merceptoethanol and oxidants like bleach and hydrogen peroxide inactivate the enzyme. The enzyme retains $88 \%$ of its activity on being mixed with commercially available detergents while it is inactivated by non-ionic Triton X 100. Its efficiency as an additive with detergent in terms of cleaning stains like grease, burnt mobil, vegetable curry and blood was found to be satisfactory. It could enhance the quality of washing as additive in case of all the ten detergents that were tried. The protease alone was also capable of cleaning but the detergent additive mixture could work better. The enzyme was found to work efficiently on different colors as well as on fabric. On mixing with detergent it was found to retain activity up to 2 months and there after, there was a drop in efficiency of washing. The bacterial cells were immobilized in calcium alginate and the released enzyme was found to be equally effective. Market surveys were carried out and the satisfactory result prompted the use of another additive (extracellular lipase) obtained from yet another bacterial strain from East Calcutta Wetland. The lipase activity was confirmed through degradation of coconut oil analyzed by Gas Chromatography. Thus the combination was observed to be more successful as indicated through the market survey. These observations suggest the suitability of the protease and lipase combination as additive to commercially available detergents.
\end{abstract}

Key words: East Calcutta Wetland, protease secreting bacteria, extracellular lipase, detergent additive

\section{INTRODUCTION}

Currently enzymes have attracted the attention of the world over due to their wide range of industrial applications in many fields including organic synthesis, clinical analysis, pharmaceuticals, detergents, food production and fermentation. Enzymes are gradually replacing the use of harsh chemicals in various industrial processes. Since they work under moderate conditions, such as warm temperatures and neutral $\mathrm{pH}$ they reduce energy consumption by eliminating the need to maintain extreme environments, as required by many chemically catalyzed reactions. The reaction specificity of the enzymes lead to minimization of the production of by-products and thereby the application of enzymes offer minimal risk to the environment.

Approximately eighty percent of all industrial enzymes are hydrolytic in nature and are used for depolymerization of natural substances i.e. the breaking down of complex molecules into simpler ones. Of these

Corresponding Author: Shaon Raychaudhuri, Department of Biotechnology, West Bengal University of Technology, Calcutta, India, 700064 
enzymes, sixty percent are proteolytic enzymes used by the detergent, dairy and leather industries ${ }^{[1]}$. Enzymes have been known to be used for improving the cleaning efficiency of detergents and are now well accepted as ingredients in powder as well as liquid detergents and industrial/ institutional cleaning products. Detergent enzymes account for about $30 \%$ of the total worldwide enzyme production and represent one of the largest and most successful applications of modern industrial biotechnology $y^{[2]}$. The performance of enzymes in detergents depends on a number of factors, viz the detergent's composition, type of stains to be removed, wash temperature, washing procedure and wash-water hardness. Besides high temperature and alkalinity, the enzyme often must withstand the presence of detergent additives such as bleaching agents, bleach activators, surfactants, perfumes etc. Out of the vast pool of enzymes, proteases from micro organisms are the most widely exploited enzymes in detergent industries ${ }^{[3]}$. They can act as minor additives or can become key ingredients in detergents. These enzymes hydrolyze protein based stains in fabrics into soluble amino acids. Among the various proteases, bacterial proteases are the most significant, compared with animal and fungal proteases. Bacterial proteases are mostly extracellular, easily produced in large amount and are often thermostable and active at wider $\mathrm{pH}$ range. Alkaline proteases from various strains of Bacillus sp. have been reported $^{[4-6]}$. There are quite a few patents of enzymatic detergent additive (European Patent EP0581839, United States Patent 4810414). Protease from Nocardiopsis sp. as well as Pseudomonas aeruginosa have also been reported to work as an additive to detergent ${ }^{[7-9]}$. One important factor to be considered during the selection of the enzyme is its stability and the shelf life of the enzymatic action. For industrial applications, the immobilization of enzyme on a solid support can offer additional advantages like repeated use of the enzyme, ease of product separation and improvement in stability $^{[10]}$.

To improve washing efficiency currently available detergents usually contain enzymes like amylase, cellulase and lipase. Amylase catalyzes the break down of starch based stains into smaller segments of oligosaccharides and dextrins which are water soluble. Lipase is used in detergent formulations to remove fat containing stains such as those resulting from frying fats, butter, salad oils etc. The enzyme hydrolyzes triglycerides into mono and diglycerides, glycerol and free fatty acids which are more soluble than fats. Lipases from different species of Pseudomonas and Acinetobacter have been reported to be used in detergent formulations ${ }^{[11]}$.
Keeping in view the diverse potential of the microbial enzymes, the present study was focused on the characterization and wash performance of detergent compatible protease and lipase from different bacterial isolates obtained from East Calcutta Wetland which is a biodiversity rich ecosystem of Calcutta. The location of this vast low lying area is such that the entire city's waste is drained into it. It in turn act as a sewage treatment plant ${ }^{[12]}$. The waste dumped into this system is further purified and recycled in activities like agriculture and pisciculture thereby generating products, economy and employment ${ }^{[13-14]}$. The purification of the waste, mostly heavy metals, is found to be a combined effort of diverse groups of planktons, water hyacinth and microbes ${ }^{[15-16]}$. Previous studies on microbial resource mapping of this area have revealed the existence of microbes belonging to 12 main bacterial phyla ${ }^{[17]}$. In that study, certain clones were found to be similar to Streptococcus macedonicus and Acinetobacter lowffi which are known to produce extracellular protease(s) and lipase(s) respectively. The growth conditions of these microbes were replicated in the laboratory to cultivate microbes from environmental samples of East Calcutta Wetland having potential of producing extracellular protease and lipase. Out of 21 isolates obtained, two were selected, one secreting protease and the other lipase with an aim to use the extracellular enzymes as additives to standard detergents.

\section{MATERIALS AND METHODS}

Microorganisms and culture conditions: The two bacterial isolates, one protease and the other lipase producing were screened out from soil samples collected at two different sites of East Calcutta Wetland, namely Green Zone (oldest portion of solid dumping ground now converted into forest ecosystem) and Captain Bheri (shallow flat bottom waste water fed fishery) respectively.

Screening of protease secreting microbes was done on solid milk medium containing $10 \%$ double toned milk, $0.3 \%$ yeast extract and $1.5 \%$ agar. Carbon minimal salt medium (CMS) containing $\mathrm{K}_{2} \mathrm{HPO}_{4}$ $2.2 \mathrm{~g} \mathrm{~L}^{-1}, \mathrm{KH}_{2} \mathrm{PO}_{4} 0.73 \mathrm{~g} \mathrm{~L}^{-1},\left(\mathrm{NH}_{4}\right)_{2} \mathrm{SO}_{4} 1 \mathrm{~g} \mathrm{~L}^{-1}, \mathrm{NaCl}$ $30 \mathrm{~g} \mathrm{~L}^{-1}, \mathrm{MgSO}_{4} 0.2 \mathrm{~g} \mathrm{~L}^{-1}$, Oil $15 \mathrm{~mL} \mathrm{~L}^{-1}$ in distilled water with $1.5 \%$ agar was used as the selective medium for isolation of lipase secreting bacteria. Luria Bertani (LB) broth containing tryptone $10 \mathrm{~g} \mathrm{~L}^{-1}$, yeast extract $5 \mathrm{~g} \mathrm{~L}^{-1}, \mathrm{NaCl} 5 \mathrm{~g} \mathrm{~L}^{-1}$ in double distilled water was used for the maintenance of the isolates and their further characterization. The pure isolates were preserved at $-80^{\circ} \mathrm{C}$ in culture medium containing $70 \%(\mathrm{v} / \mathrm{v})$ 
glycerol. All batch cultivations were carried out at $37^{\circ} \mathrm{C}$ under shaking at $150 \mathrm{rpm}$.

Characterization of isolates: The two pure isolates were characterized in terms of their morphological, biochemical and molecular nature. The detailed procedure followed for characterization was as reported by Nandy et al. ${ }^{[18]}$.

\section{Enzyme assay}

Protease assay: Two different quantification procedures were applied. One was spectrophotometric assay using hide powder azure as substrate ${ }^{[19]} .0 .5 \mathrm{~mL}$ of enzyme was added to $50 \mathrm{mg}$ of hide powder azure in $1.5 \mathrm{~mL}$ of assay buffer constituting of $50 \mathrm{mM}$ Tris- $\mathrm{HCl}$ $(\mathrm{pH}-8)$ and $1 \mathrm{mM} \mathrm{CaCl}$. The reaction mixture was incubated at $28^{\circ} \mathrm{C}$ for $1 \mathrm{~h}$. The supernatant was collected by centrifugation at $10,000 \mathrm{~g}$ for $10 \mathrm{~min}$ and absorbance was measured at $595 \mathrm{~nm}$. One unit of activity was defined as the the amount of enzyme giving an increase of 1 absorbance unit/hour.

The second assay used azocasein as substrate. $0.003 \mathrm{gm}$ of azocasein was incubated with $600 \mu \mathrm{L}$ assay buffer $\left(50 \mathrm{mM}\right.$ Tris- $\left.\mathrm{HCl}(\mathrm{pH}-7.5), 5 \mathrm{mM} \mathrm{CaCl}_{2}\right)$ and $120 \mu \mathrm{L}$ of sample at $60^{\circ} \mathrm{C}$ for $20 \mathrm{~min}$. The reaction was terminated with addition of $480 \mu \mathrm{L}$ of $15 \%$ w/v Trichloroacetic acid (TCA) and the reaction mixture was placed on ice for 10min Supernatant was collected by centrifugation at $12,000 \mathrm{~g}$ for $15 \mathrm{~min}$. Ten microliter of $10 \mathrm{M} \mathrm{NaOH}$ was added with $900 \mu \mathrm{L}$ of reaction mixture and absorbance was measured at $440 \mathrm{~nm}$. One unit of activity was defined as the the amount of enzyme required to produce an increase of 0.1 absorbance (OD at $440 \mathrm{~nm})^{[20]}$.

Lipase assay: The preliminary assay for lipase was done on Tributyrin agar medium. The procedure reported by Nandy et al. ${ }^{[18]}$ was followed. The initial quantification was done according to the diameter of the clearance zone on the triglyceride plate. The activity of the extracellular enzyme was further confirmed by Gas Chromatography (GC) taking coconut oil as substrate. From an overnight grown culture, cells were separated by centrifugation at $10,000 \mathrm{~g}$ for $10 \mathrm{~min}$. To $5 \mathrm{~mL}$ of extracellular supernatant $1 \mathrm{~mL}$ of coconut oil was added and incubated for $4 \mathrm{~h}$ at $35^{\circ} \mathrm{C}$ with shaking at $150 \mathrm{rpm}$. Post incubation $2 \mathrm{~mL}$ of chloroform was added to the above enzyme substrate mixture for extraction of the free fatty acids. After proper shaking with chloroform, $1.5 \mathrm{~mL}$ of organic phase was taken, centrifuged at $10,000 \mathrm{~g}$ for $10 \mathrm{~min}$ to ensure proper separation of organic and aqueous phase. Finally $1 \mathrm{~mL}$ of organic phase was taken, concentrated and analyzed by GC (Perkin Elmer, autosystem excel).
Characterization of Protease: The extracellular protease from one of the bacterial isolate (GZ) was characterized in its crude state. The effect of different physical and chemical factors on the activity of enzyme were checked.

Effect of pH on enzyme activity: Supernatant containing the secreted extracellular enzyme was harvested from overnight culture grown at $37^{\circ} \mathrm{C}$ by centrifugation at $10,000 \mathrm{~g}$ for $10 \mathrm{~min}$. The $\mathrm{pH}$ of the supernatant was adjusted at various values (2.0-10.5) using $\mathrm{HCl}$ and $\mathrm{NaOH}$. The mixture was preincubated for $12 \mathrm{~h}$ at $37^{\circ} \mathrm{C}$ before the hide powder azure assay was performed. To investigate the optimal $\mathrm{pH}$, protease activity at each $\mathrm{pH}$ was assayed at $37^{\circ} \mathrm{C}$ using spectrophotometric method.

Effect of temperature on enzyme activity: The enzyme activity was measured in the range of $4-60^{\circ} \mathrm{C}$ using the standard activity assay (as mentioned above) at respective temperatures. Stability of the enzyme was investigated by measuring the residual activity through hide powder azure assay after incubating the crude enzyme solution at respective temperatures for $12 \mathrm{~h}$.

Effect of protease inhibitors on enzyme activity: The effect of various protease inhibitors such as $5 \mathrm{mM}$ Phenylmethylsulphonyl fluoride (PMSF), $100 \mu \mathrm{g} \mathrm{mL}^{-1}$ Tosyl $\mathrm{L}^{-1}$ phenylalanine chloromethyl ketone (TPCK), $100 \mu \mathrm{g} \mathrm{mL}{ }^{-1}$ Tosyl $\mathrm{L}^{-1}$ ysine chloromethyl ketone (TLCK) and $100 \mu \mathrm{g} \mathrm{mL}^{-1}$ Leupeptin were determined by preincubation with the extracellular supernatant containing the enzyme at $37^{\circ} \mathrm{C}$ for $30 \mathrm{~min} 15 \mu \mathrm{L}$ of reaction mixture was assayed on milk medium plates by cup assay method. The plates were incubated at $37^{\circ} \mathrm{C}$ for overnight. The activity was measured according to the diameter of the clearing zone .

Effect of various agents on protease activity: The effect of different agents like EDTA, $\beta$ mercaptoethanol, hydrogen peroxide, Triton X-100, bleach and detergent on the bacterial protease were investigated. $5 \mathrm{mM}$ concentration of each of the above mentioned chemicals was added with extracellular supernatant, incubated at $37^{\circ} \mathrm{C}$ for $30 \mathrm{~min}$ followed by enzyme assay by cup assay method on milk medium. The activity was quantified according to the diameter of the clearing zone.

Effect of metal ions on protease activity: Various metal ions at final concentration of $5 \mathrm{mM}$ were added to the enzyme solution (extracellular supernatant. Metal salts used were $\mathrm{Al}\left(\mathrm{NO}_{3}\right)_{3} \cdot 9 \mathrm{H}_{2} \mathrm{O}, \mathrm{CuSO}_{4} \cdot 5 \mathrm{H}_{2} \mathrm{O}, \mathrm{AgNO}_{3}$, 
$\mathrm{Pb}\left(\mathrm{NO}_{3}\right), \quad \mathrm{NiCl}_{2} \cdot 6 \mathrm{H}_{2} \mathrm{O}, \quad \mathrm{HgCl}_{2}, \quad \mathrm{CrO}_{3}, \quad \mathrm{CoCl} .6 \mathrm{H}_{2} \mathrm{O}$, $\mathrm{ZnSO}_{4} \cdot \mathrm{H}_{2} \mathrm{O}$ and $\mathrm{CdCl}$. Relative protease activities were measured post incubation at $37^{\circ} \mathrm{C}$ for $30 \mathrm{~min}$. The assay was done by cup assay method on milk media plates as described previously.

Compatibility of the protease as an additive to detergents: From an overnight culture in LB medium, cells were separated by centrifugation at $10,000 \mathrm{~g}$ for $10 \mathrm{~min}$ and the cell free supernatant was mixed with standard detergent at a proportion of 6 units of enzymes $\mathrm{gm}^{-1}$ of detergent. Four different sets were prepared each having the same concentration of enzyme:detergent i.e. 1.5 units of enzyme to $0.25 \mathrm{gms}$ of detergent $6 \mathrm{~mL}^{-1}$ water. The four different conditions like just detergent and no enzyme additive, detergent with enzyme, only enzyme in water and a control of only water without any detergent or additive were tested for stain removal. Pieces of 1.5 by 1.5 inches cloth were stained with grease and dipped in above formulations followed by incubation for $1 \mathrm{~h}$ at room temperature. Post incubation each piece was rubbed using brush, rinsed with water and air dried. Densitometric scanning of the residual stain on the cloth was done using software Quantity 1 from BIORAD to check the efficiency of cleaning.

To check the compatibility of enzyme with different types of standard detergents it was mixed at the above mentioned ratio with the popular detergents of Indian market namely surf excel (Hindustan Lever Limited, Mumbai, India), Tide (Procter and Gamble, USA), Aerial (Procter and Gamble, USA), Sunlight (Unilever, South Africa), Nirma (Nirma Ltd., Ahmedabad, India), Sagar (AMOCHEM, Kolkata, India), Blue Bird (Local Make, Kolkata, India), Jet (Hindusthan Chemical Company, Kolkata, India), Soda (local make, Kolkata, India), Vim (Hindusthan Lever Limited, India). The wash performance of the enzyme acting as additive was checked by densitometric scanning of the stained cloths post washing and subsequent drying. Its efficiency on different stains were checked with grease, burnt mobile, food stain and blood. The wash performance was also checked out with different fabrics to look into its effect on the fabric quality and color. In order to check out the washing efficiency of the enzyme with time of incubation, the wash performance was checked at different time interval (10 min to $1 \mathrm{~h}$ at an interval of $10 \mathrm{~min}$ ). For each of the above case the wash performance was checked according to same procedure mentioned above.

In order to check the effect of binding of an inert matrix to the enzyme to increase its stability and washing efficiency, the extracellular supernatant containing enzyme was absorbed onto chalk powder and wash performance was carried out. The ratio of enzyme to chalk powder was the same as that with detergent. The wash performance of the enzyme under this condition was checked in the similar manner as with the normal detergent mentioned earlier. All these tests were carried out with just protease added as enzyme. The wash performance with both lipase and protease added to the detergent were subsequently checked.

Shelf life of detergent:Shelf life of the enzyme was important from the point of retention of the activity of the enzyme. The stability of the enzyme mixed with a detergent was checked over a prolonged duration of time. The wash performance of the detergent along with the protease additive was conducted at different time intervals, 15 days followed by 2 months and finally 3 months.

Market survey: The lab scale experiments were followed by large scale production of protease by fermentation in a $3 \mathrm{~L}$ Biotron fermenter. Fermentation conditions were maintained at $40 \%$ Dissolved oxygen content (DO), $150 \mathrm{rpm}$ shaking at $37^{\circ} \mathrm{C}$ for $16 \mathrm{~h}$ The cell free supernatant obtained post centrifugation was added to a standard detergent at a concentration of 6 unit of protease $\mathrm{g}^{-1}$ of detergent. The mixture was placed in trays and air dried. The dried detergent mixture in the form of powder was filled in resealable plastic bags of $500 \mathrm{~g}$ each. Two market surveys with protease as additive had been conducted among the families of different socio economic background and different localities of Calcutta. During the 2 trials 34 and 37 families respectively were distributed two $500 \mathrm{gm}$ pack of the detergent and were asked to use the same in place of their previous detergent and compare the performance of the supplied detergent. A questionarie was provided to each family to be filled up after using the detergent for one month. The filled up forms were collected and the results were expressed as pie chart.

In the third market survey, lipase from the second bacterial isolate was added along with protease to the detergent with an aim to enhance the washing efficiency. Lipase production was acheived under shake flask conditions at $37^{\circ} \mathrm{C}$ and overnight shaking at 150 rpm. The final ratio of lipase and protease in the detergent was maintained as 6 unit of protease $\mathrm{gm}^{-1}$ of detergent, $3 \mathrm{~mL}$ of crude supernatant containing extracellular lipase $\mathrm{g}^{-1}$ of detergent. The market survey had a sample size of 31 and $500 \mathrm{~g}$ of modified detergent was distributed to each and the rest of the analysis was the same. 
Cell immobilization for continuous recycling of cells for enzyme production: The washing efficiency of the enzyme as detergent additive was evident from lab scale findings as well as confirmed by market survey results. These findings guided for a application of immobilization technique which can give way to a cost efficient commercial exploitation. One percent inoculum was added to $3 \mathrm{~mL}$ of $\mathrm{LB}$ medium and incubated at $37^{\circ} \mathrm{C}$ for overnight with continuous shaking at $150 \mathrm{rpm}$. The cells were recovered by centrifugation at $10,000 \mathrm{~g}$ for $5 \mathrm{~min}$ and the cell pellet was washed with sterile Tris EDTA buffer (TE, pH 8.0). The immobilization of the cell was done as per the protocol reported by Kumar et al. ${ }^{[21]}$ with certain modifications like $8 \%$ Na-alginate solution and $1 \mathrm{M}$ $\mathrm{CaCl}_{2}$ was used. The beads were then transfered to 4 $\mathrm{mL}$ of fresh medium and incubated at $37^{\circ} \mathrm{C}$ for overnight both with continuous shaking (Set I) and under static condition (Set II). Each $24 \mathrm{~h}$ the same beads were transfered to fresh medium as innoculum. After transferring the beads the supernatant of the overnight culture was centrifuged and the cell free supernatant was added to the detergent. The efficiency of the enzyme was checked each time by observing the wash performance and monitoring the units of enzyme secreted through azocasein assay. The process was repeated until the beads were present for Set 1 . The relative cleaning and enzyme production for Set I and Set II were compared.

\section{RESULTS AND DISCUSSION}

Characterization of the microbes: Two bacterial isolates namely GZ (as isolated from green zone at $\mathrm{ECW}$ )and BS (isolated from Bheri Soil) were selected for extracellular protease (Fig. 1) and lipase production respectively. Their detailed morphological and biochechemical nature is depicted in Table 1. The isolate GZ is a novel one with $98.22 \%$ similarity with Microbacterium luteolum as depicted by the phylogenetic analysis carried out using neighbour joining method (Fig. 2). The isolate BS is as yet uncharacerized at the molecular level.

Enzyme assay: The protease assay at $37^{\circ} \mathrm{C}$ using milk media plate shows a radius of about 8 to $8.5 \mathrm{~mm}$ with $15 \mu \mathrm{L}$ of supernatant while the hide powder azure test shows the supernatant to have an enzyme concentration of 0.38-0.4 $\mathrm{U} \mathrm{mL}^{-1}$ on incubation for $1 \mathrm{~h}$.

The preliminary lipase assay was conducted with the cell free supernatant from overnight culture of isolate BS. The cup assay method on tributyrin plates gave a clearing zone of radius $7.5 \mathrm{~mm}$. The lipase activity was confirmed through GC analysis of degradation product of coconut oil which was taken as substrate. The degradation pattern of the oil as found from GC analysis was compared with those for other isolates obtained from ECW (mainly Pseudomonas Group and Acinetobacter group) (Fig. 3).

The profile for each isolate is indicated with different color. Microbes of two different types, namely Pseudomonas and Acinetobacter were studied and both show distinctly different extent of degradation of the substrate. The read color graph in the figure indicates the degraded products obtained by action of extracellular lipase from isolate BS.

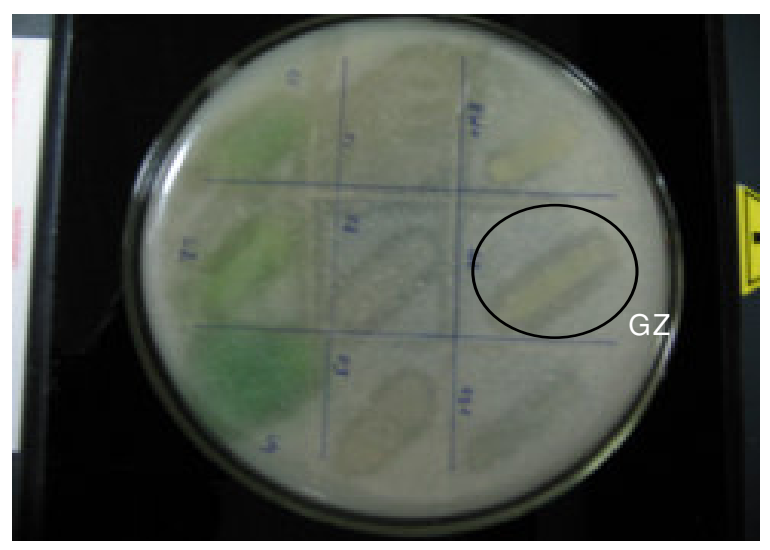

Fig. 1: Photograph of milk media plate showing extracellular protease induced clearing zone around the growth for 9 strains of bacteria. The isolate highlighted with a circle is GZ

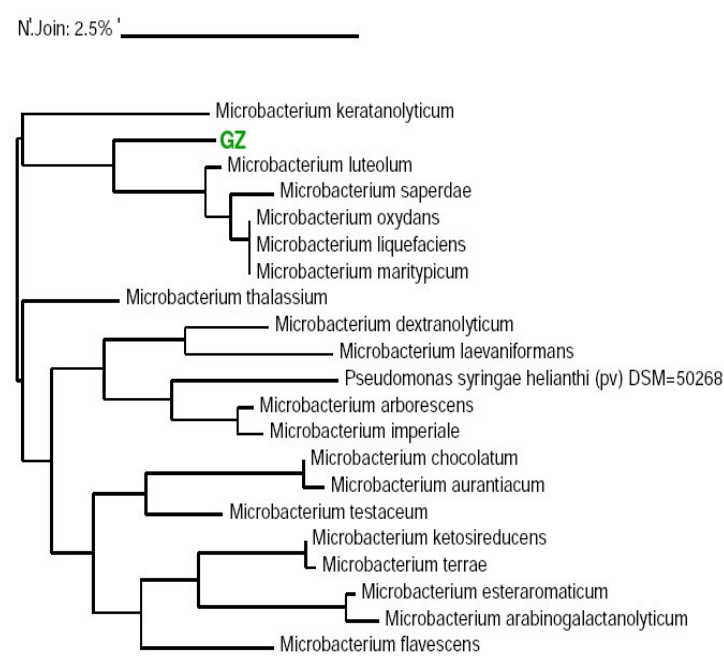

Fig. 2: Partial 16S rRNA sequence based phylogenetic analysis of isolate GZ constructed using neighbour joining method 
Am. J. Applied Sci., 5 (12): 1650-1661, 2008

Table 1: Table representing the characterization of the two isolates GZ and BS from East Calcutta Wetland.

\begin{tabular}{|c|c|c|c|c|c|c|c|c|c|c|}
\hline \multirow[b]{2}{*}{ Isolate } & \multirow[b]{2}{*}{$\begin{array}{l}\text { Site of } \\
\text { Origin }\end{array}$} & \multicolumn{2}{|c|}{$\begin{array}{l}\text { Morphological } \\
\text { Characterization }\end{array}$} & \multicolumn{5}{|c|}{ Biochemical characterization } & \multicolumn{2}{|c|}{ Molecular characterization } \\
\hline & & $\begin{array}{l}\text { Gram } \\
\text { Nature }\end{array}$ & $\begin{array}{l}\text { Cell } \\
\text { Morph }\end{array}$ & Lipase & Catalase & DNase & Oxidase & Protease & $\begin{array}{l}\text { Closest neighbor } \\
\text { /percentage similarity }\end{array}$ & $\begin{array}{l}\text { GeneBank } \\
\text { Accn. No. }\end{array}$ \\
\hline$\overline{\mathrm{GZ}}$ & $\begin{array}{l}\text { Green } \\
\text { Zone }\end{array}$ & Gm-ve & Bacilli & - & + & - & - & + & $\begin{array}{l}\text { Microbacterium } \\
\text { luteolum }(98.22 \%)\end{array}$ & EU006695 \\
\hline BS & $\begin{array}{l}\text { Soil of } \\
\text { Captain } \\
\text { Bheri }\end{array}$ & $\mathrm{Gm}+\mathrm{ve}$ & Cocci & + & + & - & - & - & Uncharacterized & \\
\hline
\end{tabular}

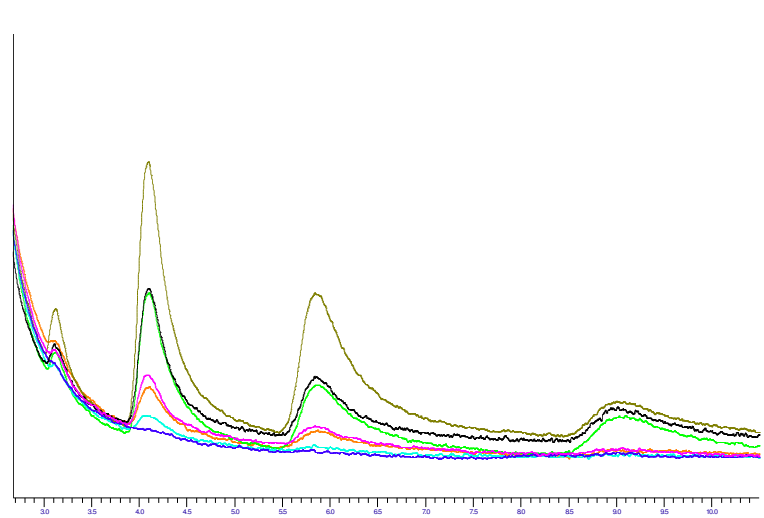

Fig. 3: GC analysis depicting the comparative action over coconut oil by extracellular lipase from 7 different isolates of East Calcutta Wetland

The light green, black and dark green graph depicts the pattern generated by Acinetobacter while pink, light blue and dark blue graphs are generated by Pseudomonas sp. from ECW.

Protease characterization: For a protease to work as a detergent additive it should be able to perform the function at alkaline $\mathrm{pH}$. Thus the activity of the extracellular enzyme in supernatant was checked at different $\mathrm{pH}$ using hide powder azure assay. The protease was checked in $\mathrm{pH}$ range of 2 to 10.5 and was found to be active in the range of 4 to 10.5 (Fig. 4a) with maximum activity at $\mathrm{pH} 7.5$. It could retain $71 \%$ of its activity at $\mathrm{pH} 10.5$ and thus could be used at alkaline $\mathrm{pH}$ as detergent additive.

The effect of temperature was checked similarly by preincubating the supernatant for $12 \mathrm{~h}$ at different temperature before performing the assay with hide powder azure as substrate. It showed activity along the entire range of 4 to $60^{\circ} \mathrm{C}$. It showed maximum activity at $30^{\circ} \mathrm{C}$ (considered as $100 \%$ ) (Fig. 4b). It retained $92.3 \%$ activity at 2 and $4^{\circ} \mathrm{C}$ while it retained 97.4, 90 and $74.4 \%$ activity at $37,40-50$ and $60^{\circ} \mathrm{C}$ respectively. This enzyme could work at high temperature retaining maximum activity and thus was suitable for application in detergent industry.
Attempts were made to determine the nature of the protease by using specific protease inhibitors. It (Fig. 4c) showed complete inhibition of activity upon treatment with PMSF (serine protease inhibitor) while partial inhibition in case of TPCK (inhibitor for proteases having Phenylalanine at the P1 cleaving site), TLCK (inhibitor of serine and other proteases) and Leupeptine (inhibitor of serine and other protease). The results indicate the presence of serine protease which is completely blocked by PMSF. The partial inhibition by Leupeptine and TLCK could be because of insufficient/lower concentration of these inhibitors used. A concentration profile with increasing amount of inhibitor could justify the above statement if complete inhibition is obtained at some higher concentration. The inhibition in case of TPCK points towards the possible presence of Phenylalanine at the position $\mathrm{P} 1$ of the cleavage site. It needs to be confirmed further.

$\beta$-merceptoethanol was found to completely inhibit protease activity. It could either be due to destabilization of thiol group at the active site and thus preventing the enzyme from binding the substrate. This could otherwise be due to destabilization of the three dimentional structure of the enzyme due to disulphide bond breakdown at other positions resulting in denaturation of the protein and so inhibition of the function. From here at this stage we could just say that it is sensitive to reducing agents. Hydrogen peroxide and Bleach were found to completely inhibit protease activity. Thus these additive could not be used with detergents containing bleaching agents as it is sensitive to free radical generating/oxidizing agents. The effect of nonionizing and commercial detergents on the protease activity was tested. The nonionic detergent completely inhibited the protease activity while with commercial detergent there was $88 \%$ activity. Thus the impact of Triton X 100 treatment might have been such that it impairs the function through disruption of the three dimentional structure of the enzyme. The effect of EDTA (Ethylene diamine tetra acetic acid) on the activity of protease was tested with preincubation in the similar manner and a remnant activity of $2 \%$ with 
Am. J. Applied Sci., 5 (12): 1650-1661, 2008
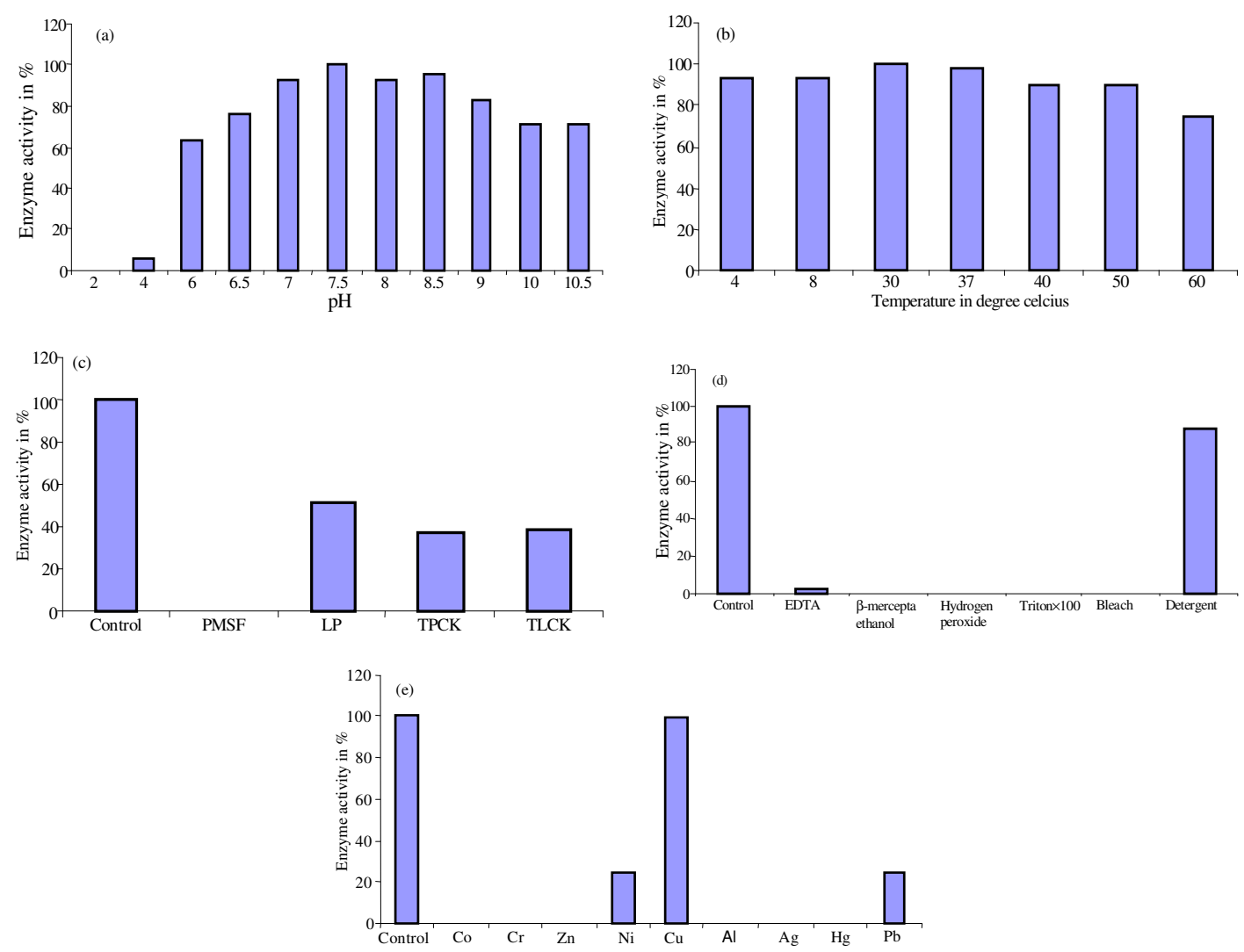

Fig. 4: Graphs representing the protease characterization in terms of the enzyme activity under conditions of different $\mathrm{pH}$, temperature, enzyme inhibitors, reducing agents and metal cations. (4a) Graph representing the effect of $\mathrm{pH}$ on enzyme activity. The activity retained after $12 \mathrm{~h}$ incubation at different $\mathrm{pH}$ was plotted with $\mathrm{pH}$ on $\mathrm{X}$ axis and the corresponding enzyme activity along the $\mathrm{Y}$ axis. The activity was plotted as the percentage of activity retained considering activity at $\mathrm{pH} 7.5$ to be $100 \%$. (4b) Graph representing the effect of different temperature over enzyme activity. The temperature scales were plotted on $\mathrm{X}$ axis while the corresponding enzyme activity in \% was depicted along Y axis. (4c) Graph representing the effect of different inhibitors on enzyme activity. Enzyme activity under native condition was considered as $100 \%$. The $\%$ of activity retained in response to specific inhibitors was plotted on $\mathrm{Y}$ axis with the inhibitors mentioned on the $\mathrm{X}$ axis. (4d) Graph representing the effect of different agents on extracellular protease activity. The activity of native protease is taken as $100 \%$ and the remaining activity as \% after treatment is plotted on the $\mathrm{Y}$ axis with agents on the $\mathrm{X}$ axis. (4e) Graph representing the effect of different metals on enzyme activity. Enzyme activity under untreated condition was taken as $100 \%$. The activity retained after incubation with metal salts was plotted on the $\mathrm{Y}$ axis with the salts listed on the $\mathrm{X}$ axis. The result shows except for $\mathrm{Cu}$ and to some extent $\mathrm{Ni}$ and $\mathrm{Pb}$, other metal ions viz. $\mathrm{Co}, \mathrm{Cr}, \mathrm{Zn}, \mathrm{Al}, \mathrm{Ag}, \mathrm{Hg}$ showed complete inhibition of enzyme activity

$5 \mathrm{mM}$ addition was obtained as compared to untreated protease. This points towards the role of divalent cations in the functioning of the enzyme (Fig. 4d).

Since metal ions are essential for the activity of the enzyme (as it was inhibited by EDTA), the effect of different salts were tested. There was $99.6 \%$ retention of activity in presence of $5 \mathrm{mM} \mathrm{CuSO} \mathrm{Cu}_{4} .5 \mathrm{H}_{2} \mathrm{O}, 25 \%$ retention of activity in presence of $5 \mathrm{mM}$ of $\mathrm{NiCl}_{2} \cdot 6 \mathrm{H}_{2} \mathrm{O}$ and $\mathrm{Pb}\left(\mathrm{NO}_{3}\right)$ while complete inhibition of activity for all the rest. Thus the protease is sensitive to metal ions (Fig. 4e).

Protease as detergent additive: The protease was used in different combinations to check its effect on the cleaning of grease stain. Stained cloth was washed with plain water, plain detergent, only protease and detergent 
Am. J. Applied Sci., 5 (12): 1650-1661, 2008
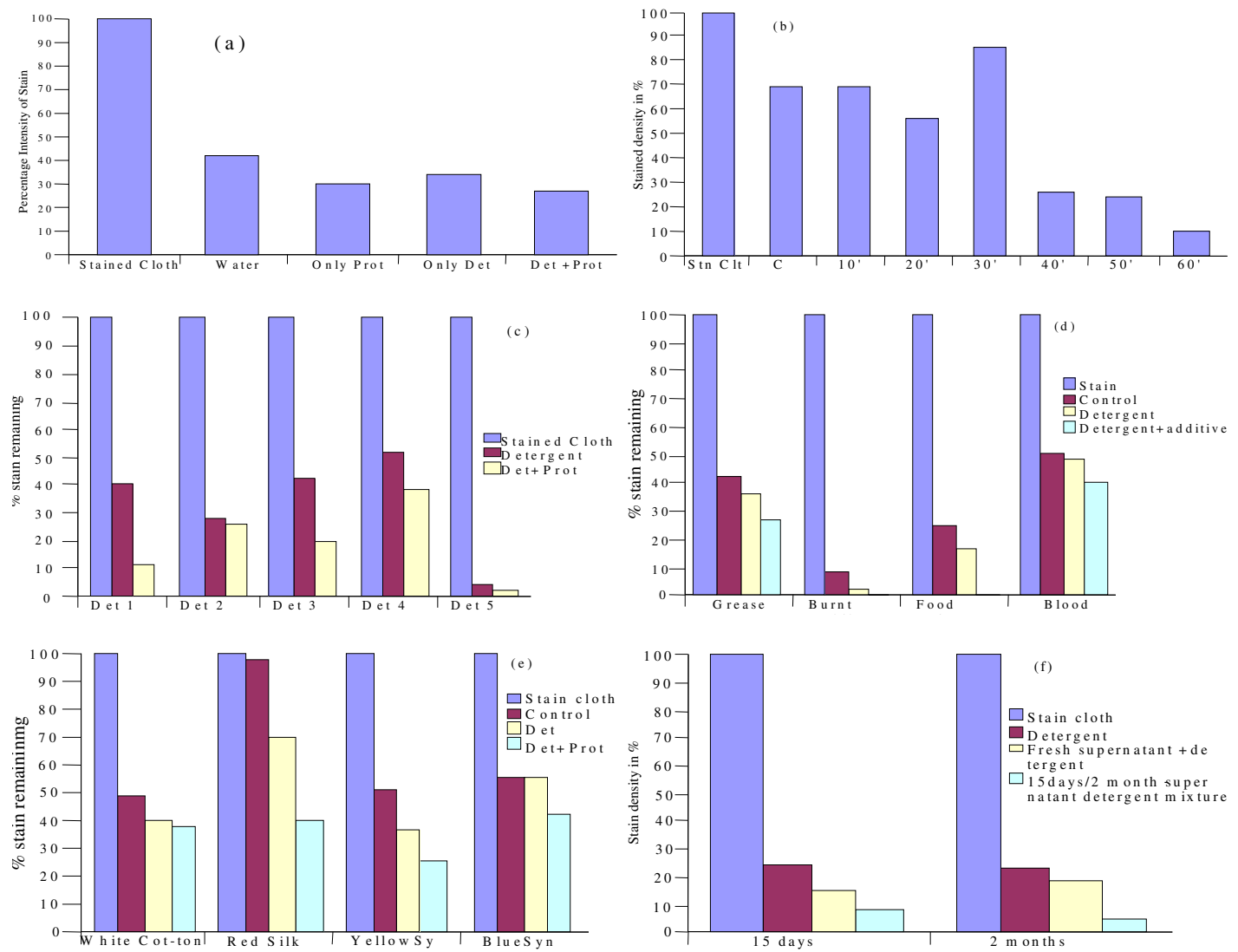

Fig. 5: Graphs representing the efficiency of the protease as detergent additive depicted in terms of its wash performance over various types of stains as well as fabric, time course of the enzyme action over stain removal, compatibility of the enzyme as a additive with different available brands of detergents. (5a) Wash performance analysis with and without addition of the protease on grease stain. The different conditions are indicated on the $\mathrm{X}$ axis while the stain intensity was on the $\mathrm{Y}$ axis. Prot stands for Protease, Det stands for Detergent while Det+Prot stands for detergent with protease. (5b) Time course of incubation of grease stained cloth with detergent and additive mixture. Stn Clt stands for stained cloth and C stands for control which is wash with just water. (5c) Graphical representation of wash performance of 5 different detergents with protease added as additive. The stain without washing was considered as $100 \%$ and there after the stain remaining on washing with detergent and detergent plus protease was compared. In each case there was enhancement of cleaning with addition of protease. Det stands for detergent. The intensity on stained cloths were taken as $100 \%$. The washed cloth with only detergent and those with detergent and protease was compared against the original stain and graphically represented in this Fig. (5d) Graphical representation of effect of the protease additive on cleaning efficiency of various stains like grease, burnt mobil, vegetable curry and blood. In each case there is increase in efficiency of cleaning with addition of protease as compared to just detergent. (5e) Graph representing the washing efficiency of the additive for different types of fabrics. Here cloths of different types and color like blood red silk, white cotton, sky blue and lemon yellow synthetic were used for the trial. The stained (grease) pieces were identically treated with just water, just detergent and detergent with protease for 1 hour and then washed as mentioned above. After drying the cloth pieces were scanned in a densitometric scanner. Y axis represents the $\%$ of residual stain post wash as compared to just stained cloth taken as $100 \%$. Det stands for only detergent and Det+Prot stands for wash with detergent containing protease as additive. Stain Cloth represents samples that have not been washed and control represents samples that have been washed only with water. 5f) The shelf life of the detergent additive mixture after 15 days and after 2 months of incubation as indicated by cleaning efficiency are depicted graphically. The efficiency increases on storage up to 2 months and thereafter there is decrease in efficiency 
with protease, dried and scanned using Quantity 1 software (BIORAD) through densitometric scanning. The intensity of stained cloth was taken as $100 \%$ and the residual intensity post wash was monitored. The percentage cleaning was the residual activity subtracted from that of stained cloth (i.e. 100). The result (Fig. 5a) indicates that the protease alone can clean better than just detergent but the best efficiency was obtained on mixing both the detergent and the protease.

A time course of incubation of the stained cloth with detergent and additive mixture was done. The stained cloths were incubated for $10 \mathrm{~min}, 20 \mathrm{~min}, 30 \mathrm{~min}$, $40 \mathrm{~min}$, 50min and $60 \mathrm{~min}$ before washing and the the results were interpreted as above following densitometric scanning (Fig. 5b). Maximum cleaning was observed after $60 \mathrm{~min}$ incubation.

Since the protease was found to work as detergent additive now the next question in hand was to check if it could work similarly for most of the commercially available detergents. This was important to know as the protease was completely inhibited by Triton X 100. Ten different detergents were tried out with all showing satisfactory enhancement of activity. Some of the results are expressed in graphical form in Fig. 5c.

Since the additive works for all types of commercial detergent thus the next approach was to test for different kinds of stains. Stains like grease, burnt mobile, vegetable curry and blood were tested. The combination of detergent with additive worked best in all the 4 cases as compared to plain water or only detergent (Fig. 5d).

The next attempt was to check the effect of the detergent additive mixture on the color as well as fabric of various kind. The mixture did not affect the color or the nature of the fabric adversely. It was used on Cotton, Silk, Chiffons, Synthetic material, etc. The result of 4 such trials are depicted below in Fig. 5e.

Immobilization of enzyme to inert matrix often increases the stability of the enzyme. Thus protease was immobilized on chalk powder and its efficiency of cleaning was checked. It did not show any improvement in performance [data not shown]. The shelf life of the additive post mixing with the detergent was checked at 15 days interval for 3 months and compared with that of the freshly mixture of additive and detergent (Fig. 5f and 6). There was retension of activity comparable to fresh mixture upto 2 months and there after there was decrease in efficiency.

Three market surveys were conducted with the first two surveys having detergent with only protease as additive. The population covered under the survey were asked to compare the cleaning efficiency of the mixture with that of their existing household detergent both in

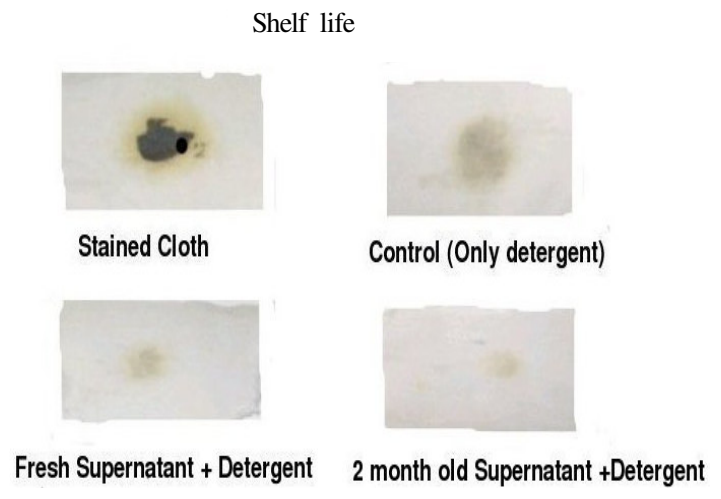

Fig. 6: Photograph showing the cleaning efficiency of the detergent with enzyme additive in different time intervals in order to check the shelf life or stability of the enzyme

terms of quality and quantity. The results were expressed as acceptable or non acceptable as represented in Fig. 7a. The mixture worked best in case of steel utensils with least preference for washing. In all four cases majority of the population found it acceptable. The distribution among families of different region and economic status ensured that irrespective of the quality of the water in different regions and irrespective of the quality of the household detergent as decided by the socio economic class, this mixture was acceptable to all.

Since the two market survey showed encouraging result, attempts were made at the laboratory for adding lipase along with protease as additive to detergent. The laboratory trial yielded positive result and the third market survey with both protease and lipase used as additive was undertaken. It was found to be much more successful as depicted in Fig. 7b.

Since the enzymes were found to work effectively as detergent additive in all the market surveys, so attempts were made to simplify the process of obtaining additives at the commercial scale. $1 \%$ cells of both the type (isolate GZ and BS) were immobilized in calcium alginate separately and the entrapped cells were used as inoculum for twenty rounds of growth. Results indicate that there is increase in enzyme secretion with shaking as compared to stationary condition. This might be due to the variation in dissolved oxygen concentration as evident from the DO measurement $(0 \%$ under static condition, 57\% immediately after shaking and $72 \%$ during shaking). The enzyme production was monitored in each cycle and found to be relatively stable throughout the 20 cycles both for static and shaking condition. There cleaning efficiency of both the additives from static as well as stationary conditions 
Am. J. Applied Sci., 5 (12): 1650-1661, 2008
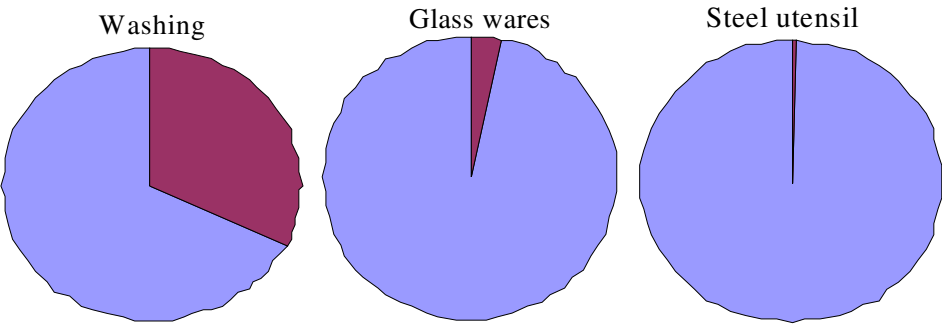

(a)
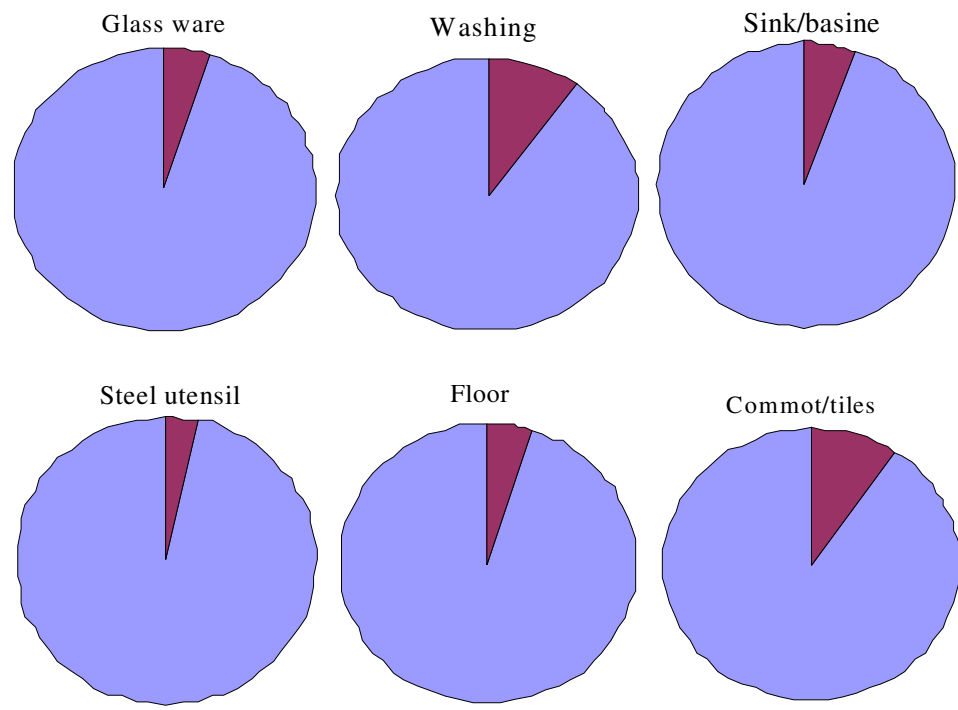

(b)
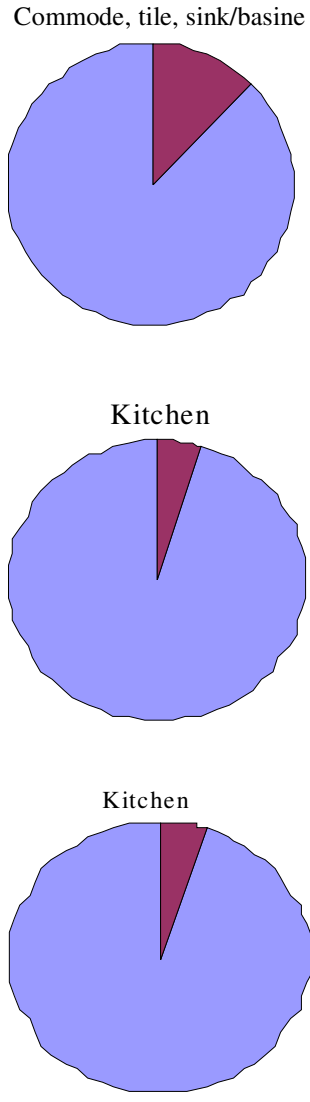

Fig. 7: Graphs representing the acceptability of the enzymes, protease and lipase as additives to detergents as derived from market survey. 7a) Graphs representing the results of market survey with only protease added as additive to detergent. 7b) Graphs representing the results of market survey with protease and lipase added as additive to detergent. In all cases mauve represents acceptable and maroon represents not acceptable

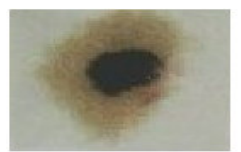

Stained cloth

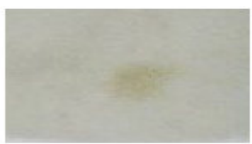

\section{Detergent} +additive from cell grown in normal condition

Fig. 8: Photograph showing the cleaning efficiency of the detergent with enzyme additive under the condition of enzyme production by immobilized cells

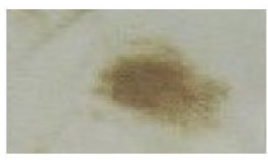

\section{detergent}

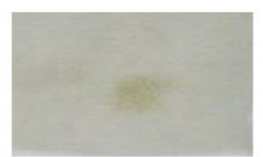

\section{Detergent+ additive} from immobilised cell

(immobilized state) were checked and found to be comparable to that of fresh mixture of detergent and additives from liquid culture (free cells). It is to be noted that the efficiency of cleaning was better under shaking as compared to stationary condition which might be due to higher enzyme production (with activity of enzyme in supernatant under shaking condition as $1 \mathrm{U}$ while that for static as $0.5 \mathrm{U})$. The comparison of the result of cleaning under free as compared to immobilized condition is provided in Fig. 8.

\section{CONCLUSION}

In this reserch we report for the first time the detection of laundry detergent compatable extracellular protease from a novel bacterial strain showing maximum similarity with Microbacterium luteolum 
among the cultivable microbes. We also report the presence of detergent compatible extracellular lipase activity from a bacterial isolate showing similarity to Acinetobacter $s p$ as proved by the degradation pattern of coconot oil through GC analysis. Both these isolates are obtained from the unique site of East Calcutta Wetland in Calcutta, India, which happens to be the world's largest dumping ground and treatment site for solid as well as soluble waste covering an area of $12500 \mathrm{Ha}$.

\section{ACKNOWLEDGEMENT}

The authors would like to acknowledge the financial support of Department of Science and Technology, India, Department of Biotechnology, India, Inter University Consortium Calcutta Centre and Board of Research in Nuclear Sciences, Department of Atomic Energy, India. They would thank West Bengal University of Technology for providing the computational as well as Bioinormatics Infrastructure Facility (DBT, GOI supported). We are also thankful to the participants of the Market survey for providing us with the filled in market survey questionaire in time.

\section{REFERENCES}

1. Rao, M.B., A.M. Tanksale, M.S. Ghatge and V.V. Deshpande, 1998. Molecular and Biotechnological aspects of Microbial proteases. Microbiol. Molecular Biol. Rev., 62: 597-635.

2. Research and Application of Microbial EnzymesIndia's Contribution, 2003. Advances in Biochemical Engineering/Biotechnology, 85: 95-124.

3. Ganesh Kumar, C. and H. Tyagi, 1999. Microbial alkaline protease: From a bioindustrial viewpoint. Biotechnol. Adv., 17: 561-594.

4. Banik, R.M. and M. Prakash, 2004. Laundry detergent compatibility of the alkaline protease from Bacillus cereus. Microbiol. Res., 159 (2): 135-140.

5. Oberoi, R., Q.K. Beg, S. Puri, R.K. Saxena and R. Gupta, 2001. Characterization and wash performance analysis of an SDS stable alkaline protease from a Bacillus sp. World J. Microbiol. Biotechnol., 17 (5): 493-497.

6. Nascimento, W.C.A. and M.L.L. Martins, 2006. Studies on the stability of protease from Bacillus sp. and its compatibility with commercial detergent. Brazilian J. Microbiol., 37: 307-311.
7. Albuquerque, M.K.A., B.F. Teixeira, M.F.S. Porto and A.L.F. Lima Filho, 2002. Application of protease from Nocardiopsis sp. as a laundry detergent additive. World J. Microbiol. Biotechnol., 18 (4): 309-315(7).

8. Najafi, M.F., D. Deobagkar and D. Deobagkar, 2005. Potential application of protease isolated from Pseudomonas aeruginosa PD100. Electronic J. Biotechnol., 8(2): 197-203.

9. Howe, T.R. and B.H. Iglewski, 1984. Isolation and characterization of alkaline protease-deficient mutants of Pseudomonas aeruginosa in vitro and in a mouse eye model. Infect. Immunity, 43 (3): 1058-1063.

10. Ahmed, S.A., S.A. Saleh and A.F. Abdel-Fattah, 2007. Stabilization of Bacillus licheniformis ATCC21415 alkaline protease by immobilization and modification. Aust. J. Basic Applied scie., 1 (3): 313-322.

11. Hasan, F., A.A. Shah and A. Hameed, 2006. Industrial applications of microbial lipases. Enzyme Microbiol. Technol., 39: 235-251.

12. Ray Chaudhuri, S., M. Mishra, P. Nandy and A.R. Thakur, 2008. Waste management: A case study of ongoing traditional practices at East Calcutta Wetland. Am. J. Agric. Biol. Sci., 3: 315-320.

13. Chaudhuri, S.R., S. Salodkar, M. Sudarshan and A.R. Thakur, 2007. Integrated Resource Recovery at East Calcutta Wetland-how safe is these? Am. J. Agric. Biol. Sci., 2: 75-80.

14. Raychaudhuri, S., M. Mishra, S. Salodkar, M. Sudarshan and A.R. Thakur, 2008. Traditional Aquaculture Practice at East Calcutta Wetland: The Safety Assessment. Am. J. Environ. Sci., 4 (2): 140-144.

15. Pradhan, A., P. Bhaumik, S. Das, M. Mishra, S. Khanam, B. Amin Hoque, I. Mukherjee, A.R. Thakur and S.R. Chaudhuri, 2008. Phytoplankton diversity as indicator of water quality for fish cultivation. Am. J. Environ. Sci., 4 (4): 271-276.

16. Chaudhuri, S.R., S. Salodkar, M. Sudarshan, I. Mukherjee and A.R. Thakur. Role of Water hyacinth mediated Phytoremediation in Waste Water Purification at East Calcutta Wetland. Environ. Sci., Accepted.

17. Raychaudhuri, S. and A.R. Thakur, 2006. Microbial genetic resource mapping of East Calcutta Wetland. Curr. Sci., 91: 212-217. 
18. Nandy, P., A.R. Thakur and S.R. Chaudhuri, 2007 Characterization of bacterial strains isolated through microbial profiling of urine samples. Online J. Biol. Sci. 71(1): 44-51.

19. Ching-Hsing, L. and D.E. McCallus, 1998. Biochemical and Genetic Characterization of an extracellular protease from Pseudomonas fluorescens CY091. Applied Environ. Microbiol., 64 (3): 914-921.
20. Koeabryik, S. and B. Erden, 2002. Intracellular alkaline proteasse produced by thermoacidophiles: Detection of protease heterogeneity by gelatin zymography and polymerase chain reaction (PCR). Bioresource Technol., 84 (1): 29-33.

21. Kumar, S.R. and M. Chandrasekharan, 2003. Continuous production of L-glutaminase by an immobilised marine Pseudomonas sp BTMS-51 in a packed bed reactor. Process Biochem., 38: 1431-1436. 